DOI: https://doi.org/10.32839/2304-5809/2021-5-93-15

УДК 37.02

Томашевська Г.П.

Центральноукраїнський державний педагогічний університет імені Володимира Винниченка

\title{
РОЛЬ НАУКОВОЇ ДИСКУСІЇ В ДОСЛІДЖЕННІ РЕЗУЛЬТАТІВ ЕКСПЕРИМЕНТІВ З РОЗКРИТТЯ ПРИРОДИ ГРАВІТАЦІЙНОГО ПОЛЯ
}

Анотація. У статті показано роль наукової дискусії в дослідженні результатів експериментів. Зазначено, що здатність до творчої діяльності формуеться у шкільному віці. Запропонована методика навчання теорії відносності та гравітації з допомогою наукової дискусії, заснованої на новітніх даних $з$ ядерної фрізики, астрофрізики, теорії гравітації, теорії еволюції Всесвіту. На основі пояснення цих питань показано розвиток інтелектуального мислення. Показано, що метою дискусії є пошук правильного рішення. В атмосфері дискусії виявляються такі особистісні властивості, як самостійність, нонконформізм. У діловому спілкуванні вчені спеціально організовують і використовують дискусію як метод дослідження. Перед закладами шкільної освіти стоїть завдання розвитку продуктивного мислення, як невід’емної складової творчого потенціалу. Цього можна досягти на прикладі ведення дискусії. Навички продукування інтелектуальних цінностей розвиваються в результаті розумової активності. Серед видів діяльності, що сприяють інтелектуальному розвитку і є дискусія. Важливою є організація дослідження, що базуеться на основі вивчення сучасних проблем експериментальної фізики, які вирішуються методами наукової дискусії. Як свідчать дослідження, учні, внаслідок недостатньої сфрормованості відповідних умінь, недостатньо оріентуються у виборі методів досліджень, зазнають труднощів у формулюванні гіпотези на підставі відомих фрактів, не можуть запропонувати експеримент для підтвердження гіпотези. Озброєння учнів методологічними знаннями з ведення дискусії - $є$ необхідною складовою гуманізації фізичної освіти. Переважна більшість навчальних завдань дослідницького характеру спрямована на організацію емпіричної діяльності, є лише незначна кількість завдань на організацію суто теоретичного дослідження. Такий дисбаланс не дозволяе учням 3 перевагою теоретичного стилю мислення реалізувати свої здібності.

Ключові слова: гіпотези,фундаментальні взаємодії, природа маси, бозон Хіггса, польова теорія.

Tomashevska Hanna Central Ukrainian State Pedagogical Universiti named after Volodymyr Vynnychenko

\section{THE ROLE OF SCIENTIFIC DISCUSSION IN THE STUDY OF THE RESULTS OF EXPERIMENTS ON THE DISCLOSURE OF THE NATURE OF THE GRAVITATIONAL FIELD}

Summary. The article shows the role of scientific discussion in the study of experimental results. It is noted that the ability to be creative is formed at school age. A method of teaching the theory of relativity and gravity with the help of a scientific discussion based on the latest data from nuclear physics, astrophysics, the theory of gravitation, the theory of the evolution of the universe is proposed. Based on the explanation of these issues, the development of intellectual thinking is shown. It is shown that the purpose of the discussion is to find the right solution. In the atmosphere of discussion such personal qualities as independence, non conformism are revealed. In business communication, scientists specifically organize and use discussion as a research method. The process of controversy is based on a contradiction that must be identified to formulate a problem (put forward a thesis and antithesis). Schools face the challenge of developing productive thinking as an integral part of their creative potential. This can be achieved through the example of discussion. Skills of producing intellectual values develop as a result of mental activity. Among the activities that promote development is discussion. It is important to organize a study based on the study of modern problems of experimental physics, which are solved by methods of scientific discussion. According to research, students, due to insufficient development of relevant skills, are insufficiently oriented in the choice of research methods, have difficulty formulating a hypothesis based on known facts, can not offer an experiment to confirm the hypothesis. Equipping students with methodological knowledge for discussion is a necessary component of the humanization of physical education. The vast majority of educational research tasks are aimed at the organization of empirical activities, there are only a small number of tasks for the organization of purely theoretical research. This imbalance does not allow students with a predominance of theoretical thinking to realize their abilities. Discussion in the interaction of scientists is usually an organized debate: it is planned, prepared, and then analyzed. The article shows the main structural elements of the discussion. It is shown that it is necessary to choose a strategy of treatment taking into account individual features. Depending on the level of competence, there are strong and weak participants. The attitude of the presenter to the listeners should be differentiated. The organizer should stimulate the audience to make statements - ask sharp questions. An example of a scientific discussion on the topic: "Is there a Higgs boson?". It is emphasized that scientists believe that fundamental interactions are carried by quanta. In the process of interaction, a physical object emits particles - carriers of interaction, which are absorbed by another object.

Keywords: the hypothesis, fundamental interactions, the nature of mass, a Higgs boson, the field theory. 
$\prod^{\circ}$ остановка проблеми. Життя є проявом суперечок та дискусій. Вчені, в процесі дослідження, постійно шукають якісь істини. Одним подобається вести дискусії, іншим - ні, але всі ми, в деякій мірі, беремо участь у різних дискусіях.

Дискусія (від лат. Discussion - “дослідження”) - це публічний діалог, у процесі якого зіштовхуються протилежні точки зору. У риториці дискусія - це обговорення проблеми, спосіб її колективного дослідження, коли кожна зі сторін відстоюе свою правоту. Прагнення зайняти власну позицію - вагома потреба людини, пов'язана 3 самоствердженням, в атмосфері дискусії виявляються такі особистісні властивості, як самостійність, нонконформізм.

Суперечки емоційно притягують, є цікавими і постійно супроводжують нас.

У діловому спілкуванні вчені спеціально організовують і використовують дискусію як метод дослідження. Процес суперечки заснований на протиріччі, яке треба виявити, щоб сформулювати проблему (висунути тезу і антитезу). Здатність до творчої діяльності формуеться у шкільному віці. Перед закладами шкільної освіти стоїть завдання розвитку продуктивного мислення, як невід'ємної складової творчого потенціалу. Цього можна досягти на прикладі ведення дискусії. Фізика, як навчальна дисципліна, має значні можливості розвитку мислення. Деякі методисти розглядали ряд аспектів цієї проблеми. Навички продукування інтелектуальних цінностей розвиваються в результаті розумової активності. Серед видів діяльності, що сприяють інтелектуальному розвитку і є дискусія.

Озброєння учнів методологічними знаннями 3 ведення дискусії - $€$ необхідною складовою гуманізації фрізичної освіти. Більшість навчальних завдань дослідницького характеру спрямована на організацію емпіричної діяльності, $є$ лише незначна кількість завдань суто теоретичного характеру. Такий дисбаланс не дозволяе учням 3 перевагою теоретичного стилю мислення реалізувати свої здібності. Використання спеціалізованих видань одночасно 3 підручниками розширюе можливості учнів в отриманні інформації, спонукає до порівняння та аналізу, розширює горизонт знань.

Аналіз останніх досліджень i публікацій. Проблема розвитку продуктивного мислення учнів на основі дискусії є важливою та багатогранною.

Принципи наукового спілкування досліджувала Буєва Л.П. [3]. Критерії розвитку особистості досліджував Бурлачук Л.Ф., Келесі М. [4] Психологічні особливості професійної підготовки спеціалістів досліджував Возняк Л.С. [6]. Розумову діяльність школярів досліджували Вайтгеймер М., Тализіна Н.Ф. [12], Гальперін П.Я. [8] та ін. Серед науковців, що досліджували природу творчих здібностей, слід відмітити Богоявленську Д.Б. [2], Лернера I.Я. [10], Матюшкіна О.М. [11]. Ряд відомих методистів фрізики розглядали окремі аспекти проблеми розвитку творчих здібностей: Атаманчук П.С. [1], Будний Б.Є., Разумовський В.Г., Ляшенко O.I., Малафрєев P.I. Дидактичні засади впровадження дослідження у практику навчання фізики розроблялись Галатюком Ю.М. [7], Жуком Ю.О., Котельниковим Г.О., Тищуком В.I., Шутом M.I. [13].
Виділення не вирішених раніше частин загальної проблеми. Протягом навчання учні постійно дискутують на різні теми, адже під час суперечки народжується істина. Тому виникає питання, як правильно вести дискусії. Метою дискусії є пошук правильного рішення.

Там, де пануе авторитарна система мислення, не будуть успішно розв'язуватися важливі задачі.

Перед закладами шкільної освіти стоїть завдання розвитку продуктивного мислення.

Важливою є організація дослідження, що базується на основі вивчення сучасних проблем експериментальної фрізики, які вирішуються методами наукової дискусії. Питання спрямованості дослідницьких завдань на формування вмінь застосовувати ті чи інші елементи методів наукового пізнання залишається ще не повністю розв'язаним.

Як свідчать дослідження, учні, внаслідок недостатньої сформованості відповідних умінь, недостатньо орієнтуються у виборі методів досліджень, зазнають труднощів у формулюванні гіпотези на підставі відомих фрактів, не можуть запропонувати експеримент для підтвердження гіпотези.

Переважна більшість навчальних завдань дослідницького характеру спрямована на організацію емпіричної діяльності, є лише незначна кількість завдань на організацію суто теоретичного дослідження.

Мета статті. Головною метою цієї роботи є: навчити учнів умінню правильно вести дискусію; показати роль наукової дискусії в дослідженні результатів експериментів; виробити в учнів здатність до творчої діяльності; запропонувати методику навчання теорії відносності та гравітації з допомогою наукової дискусії, заснованої на новітніх даних з ядерної фізики, астрофізики, теорії гравітації, теорії еволюції Всесвіту.

Виклад основного матеріалу. Дискусія у взаємодії науковців - це, як правило, організована суперечка: вона плануеться, готується, а потім аналізуеться [3]. Основні структурні елементи дискусії:

- доколунікативний етап (формулювання проблеми): оголошення теми, мети, уточнення понять; збір інформації 3 предмету суперечки, визначення понять;

- колунікативний етап (висування і захист тези): добір аргументів; спростування тези й аргументації оппонента; формулювання питань до опонентів;

- постколунікативний етап (підведення підсумків): оцінка аудиторії; аналіз дискусії.

Докомунікативний етап служить для того, щоб срормулювати проблему, тобто висунути тезу (думку, для обтрунтування якої вибудовуеться доказ) і антитезу (протилежну думку). Для цьог, за допомогою енциклопедій, словників, визначаються ключові поняття. Потім з'ясовуеться, чи є думка достовірна чи тільки ймовірна. Необхідно, щоб теза й антитеза були простими та лаконічними. Далі збирають і класифікують усі необхідні знання про предмет, уточнюють значення понять, термінів, продумують аргументи для доказу тези, формулюють питання та полемічні прийоми. Необхідно вибрати стратегію поводження з урахуванням індивідуальних особливостей. В залежності від рівня компетенщії, виділяють силь- 
них і слабких учасників. Сильний учасник добре знає предмет суперечки, упевнений в собі, логічно міркує, має досвід полеміки. Слабкий учасник недостатньо глибоко знає проблему, нерішучий не має досвіду з ведення поллеміки. За характером, учасники діляться на “лисиць" і “іжаків", згідно з висловлюванням Архілоха: "Лисиця знає багато всяких речей, а їжак - одну, але велику”. Таким чином, “лисиці” - люди широко освічені, але в чомусь недостатньо компетентні, а “їжаки” - заглиблені в одну тему. В залежності від активності, $€$ такі типи учасників: співчутливі (ведуть обговорення 3 зацікавленістю), дуже активні (украй зацікавлені проблемою), потенційні (нейтрально ставляться до проблеми), скептики (не беруть участі в суперечці).

Ставлення ведучого до слухачів має бути диференційованим: сильному ставлять важкі питання, до “іжака" звертаються за поясненням, скептиків намагаються втягнути в обговорення проблеми.

Дискусія відкривається вступнил словол організатора. Він повідомляе тему, дає їі обгрунтування, виділяе предмет суперечки - положення і судження, що підлягають обговоренню. Учасники дискусії повинні чітко уявляти, що є пунктом розбіжностей, бути впевненими, що немає термінологічної плутанини. Тому ведучий визначає основні поняття через контрастні явища, конкретизатори, синоніми. Сторони аргументують тезу, а також заперечення до викладених точок зору, ставлять питання.

Організатор має стимулювати аудиторію до висловлювань - ставити гострі питання, якщо суперечка згасає, направляти діалог на відповідність темі, підкреслювати те загальне, що є у висловах опонентів. Завершуючи дискусію, учасники відзначають результат, формують варіант погодженої точки зору чи позначають виявлені позиції. Ведучий, у заключному слові, характеризуе стан питання, відзначае конструктивні, переконливі виступи, тактовну поведінку комунікантів.

Правила ведення дискусї̈: 1) Всі відкрито висловлюють свої думки. 2) Всі точки зору поважаються. 3) Всі повинні слухати не перебиваючи. 4) Опоненти не повинні говорити занадто довго i часто. 5) Водночас говорить лише одна особа. 6)Всі повинні дотримуватися позитивних ідей та стосунків. 7) Заперечувати треба, коли ви впевнені, що думка співрозмовника дійсно суперечить вашій. 8) Спочатку наводьте тільки сильні докази, про слабкі говоріть після і мимохідь. 9) Спростовуйте фрактами те, що теза протилежної сторони не випливае з аргументів. Не наполягайте на запереченні доказів опонента, якщо вони є очевидні. 10) У процесі суперечки намагайтеся переконати, а не вразити, пам'ятаючи, що повага до чужих переконань - ознака поваги до особистості. 11) Умійте зберігати спокій і володіти собою.

Аналіз дискусї - це останній, заключний етап, що передбачає ретельне осмислення процесу спілкування. Для цього використовують такі питання:

1. Що обговорювалося і що повинно було дати обговорення?

2. Чи доведена ведучим значимість проблеми?

3. Наскільки просто, ясно і стисло фрормулюються теза й антитеза?
4. Чи вдалося домогтися однакового семантичного розуміння термінів, понять?

5. Як аргументується теза та спростовується антитеза?

6. Що спільного і різного, у підсумку, виявлено в позиціях сторін?

7. Чи відповідає мета отриманим результатам (цілком, частково, мало)?

8. Хто найбільш дипломатичний, творчий, інтелігентний учасник обговорення?

Важливим $є$ не лише правильна організація дискусії, але й культура мовлення. Не так багато є людей, які у ході суперечки дотримуються культури мовлення. Кожна сторона повинна мати рівні можливості. Не можна використовувати недозволені методи ведення суперечок: ображати один одного, натякати на недоліки або негативні сторони опонентів, відносити до суперечок речі, які не мають відношення до питань, що розглядаються. Треба пам'ятати, що образити людину легко, а відновити стосунки важко. Перш ніж щось сказати, подумайте про наслідки.

Розглянемо приклад наукової дискусії на тему: "Чи існує бозон Хіггса".

Тема дуже актуальна, оскільки, на даний момент не існує єдиної теорії гравітації, отже спробуємо розібратися в цьому питанні на основі наукової дискусії.

ВИКЛАД ТЕЗИ: “Так, бозон Хіггса існує”.

Різноманіття властивостей Природи обумовлене взаємодією елементарних частинок. Всю різноманітність фрізичних процесів можна пояснити існуванням фондаментальних взаємодій: слабкої, сильної, електромагнітної, гравітаційної. Це ті “стихії”, які рухають небесні тіла, породжують світло, уможливлюють життя.

Фізика розглядає передачу взаємодії між тілами за допомогою полів, що розподілені в просторі. Але електромагнітні і гравітаційні взаємодіï не пояснюють, що утримуе нуклони в ядрі. У 30 -х роках було постульовано існування сильної взаємодії. Цього було недостатньо і тоді постулювали існування слабкої взаємодії. Для аналізу взаємодій використовують дві характеристики: константу взаємодії, яка визначає величину взаємодії, і радіус дії. Якщо радіус малий, то взаємодії називають короткодіючими, вони діють на відстанях, менших $10^{-12}$ см. Їх інтенсивність швидко зменшуеться зі збільшенням відстані.

Вважається, що фрундаментальні взаємодії переносяться квантами. У процесі взаємодії фрізичний об'єкт випускає частинки - переносчики взаємодії, які поглинаються іншим об'єктом, при цому, об'єкти ніби відчувають один одного, їх енергія, характер руху, стан - змінюються. Фізики Г. Джорджі і Ш. Глешоу, припустили, що під час переходу до високих енергій відбудеться злиття електрослабкої і сильної взаємодії. Це отримало назву теорії “Великого об’єднання”. Згідно з цим, існує лише два типи взаємодій: об'єднана і гравітаційна. Не виключено, що всі чотири взаємодії є лише окремими проявами єдиної взаємодії, що виявляе себе в конкретних ситуаціях як гравітаційна, або як слабка, або як електромагнітна, або як сильна, або як їх комбінація. Гравітаційна взаємодія характерна для всіх матеріальних об’ектів. Всяка частинка перебуває під впливом гравітаційної сили, що залежить від маси і енергії 
частинки. Передбачається, що гравітащійна взаємодія обумовлена гравітонами. Гравітон не володіє масою, відповідна йому сила є далекодіючою. Гравітони поширюються у вигляді хвиль, але їх важко зареєструвати. Гравітаційні сили діють на великих відстанях і завжди є силами тяжіння. Гравітаційна взаємодія в 1039 разів менше взаємодії електричних зарядів, але, оскільки вона діє на будь-яких відстанях і всі маси позитивні, це дуже важлива сила. Завдяки далекодії гравітація не дозволяе Всесвіту розпастися на частини. Вона утримуе планети на орбітах, зірки в галактиках, галактики в скупченнях, скупчення в Метагалактиці. Гравітаційне відштовхування ніколи не спостерігалося [9]. Природа маси - важливе, до цих пір ще не вирішене питання фрізики. Релятивіська механіка вважає, що не існуе окремо законів збереження маси і енергії. Це природньо, бо матерію (кількість якої характеризуе маса) не можна уявити без руху (кількість якого характеризуе енергія). Вважається, що маси елементарних частинок визначаються полями, які з ними зв'язані. Гравітаційні хвилі цього поля було зареєстровано 14 вересня 2015 року в 5:51 ранку за літнім північноамериканським східним часом (12:51 за київським часом) на двох детекторах-близнюках лазерної інтерферометричної гравітаційно-хвильової обсерваторії LIGO, розташованих в Лівінгстоні (штат Луїзіана) і Хенфрорді (штат Вашингтон ) в США. Детектори LIGO виявили відносні коливання величиною в $10^{-19}$ метрів [14]. Але до цьго часу не створена кількісна теорія маси. Не існуе теорій, що пояснюють, чому маси елементарних частинок утворюють дискретний спектр значень і які б дозволяли розрахувати ці значення. В сучасній фізиці існуе квантова теорія поля, що вважає, що будь-яке поле дискретне. Квантова гравітація - напрям досліджень в фрізиці, метою якого є квантовий опис гравітаційної взаємодії.

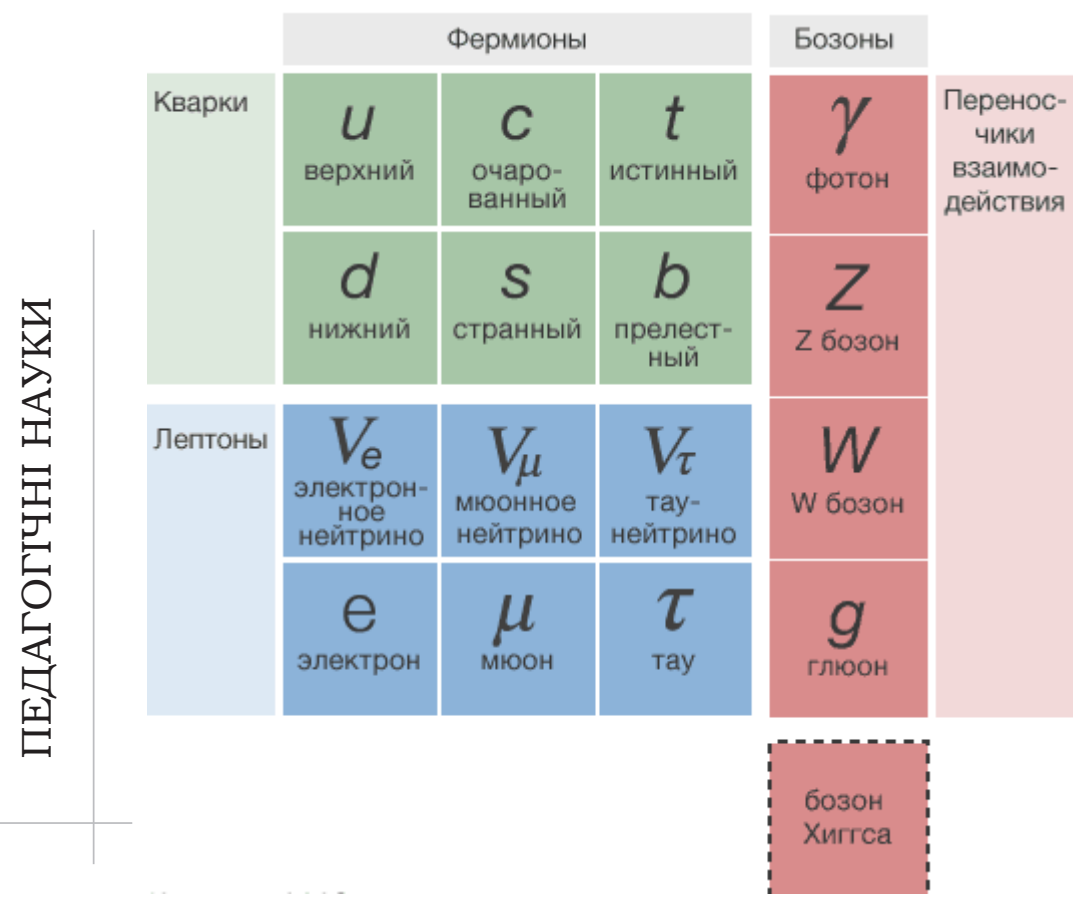

Рис. 1. Стандартна модель

Джерело: [15]
Для переходу до квантової гравітації потрібно замінити системи на квантові, це вимагае квантування геометрії простору-часу. При низьких енергіях, згідно квантової теорії поля, гравітаційну взаємодію можна пояснити обміном гравітонами - калібрувальними бозонами зі спіном 2 [5].

На брифінзі в Женеві 3.7.2012 вчені, які працють на Великому адронному колайдері (BAК), заявили про виявлення частинки, параметри якої відповідні до параметрів бозона Хіггса [15]. Два експерименти, проведені на ВАК, дають підтстави підозрювати утворення бозонів однакової маси. Над проблемою працюють дві групи учених, використовуючи різні детектори - Atlas i CMS, - принцип дії яких базуеться на різних технологіях. Бозон Хіггса довгі роки існував тільки в думках фізиків-теоретиків. Гіпотеза про те, як побудований Всесвіт - частинки, що фрормують атоми, молекули, матерію, сили, що приводять все це в рух - отримала назву “Стандартна модель” (рис. 1). Але в цій теоретичній конструкції є недолік - вона не пояснює, яким чином всі ці частинки отримують масу. В 1964 році група вчених, в яку входив Пітер Хіггс, запропонувала своє пояснення цього процесу, що отримало назву "механізм Хіггса". За відсутності маси, всі елементарні частинки, що формують атоми, рухалися б зі швидкістю світла і не були б спроможні сдормувати матерію. Згідно з механізмом Хіггса, Весвіт пронизує поле Хіггса, яке дає змогу частинкам отримати масу. Вважаеться, що взаемодія в цьому полі з бозонами Хіггса наділяе рухливі елементи масою. За допомогою прискорювачів, вчені, спостерігаючи за зіткненнями субатомних частинок - протонів, на швидкостях, близьких до швидкості світла, шукають бозон Хіггса. Ці зіткнення породжують множину ще менших частинок, які можна виділити тільки таким шляхом.

Сам бозон Хіггса в чистому вигляді не можна спостерігати, але вчені зробили спробу знайти його короткочасний прояв в потощі частинок, після зіткнення в колайдері. Він розпадається на ще менші складові, що сформують шлейфр, що підтвердить його існування. Експеримент на ВАК показав, що знайдена нова елементарна частинка з масою 126 ГеВ, що розпадається на два фотони, вона нейтральна, має спін 0 чи 2 (продукти розпаду мають спін, рівний 1), вона нестабільна, зафіксований в експерименті на ВАК час існування частинки менше секунди [15].

Запитання опонента:

- Чолу прибічники стандартної моделі побачили в новій частинці бозон Хіггса? Наявність двофотонного розпаду ще не $\epsilon$ доказом, що елементарна частинка $є$ бозон Хіггса? Двофотонний розпад характерний і для мезонів зі спіном $0(\pi 0, \eta 0)$.

- Чи існують кварки в природі? Польова теорія вирішила завдання систематизації частинок, а місця для кварків і глюонів в ній не знайшлося і гравітони не зв'язують елементарні частинки в єдине ціле. Отже, існування кварків ще не доказане.

- Чи існують віртуальні частинки? Квантова теорія стверджує, що елементарні 
частинки знаходяться як в реальному, так і в віртуальному стані. Польова теорія це заперечуе.

- Що таке ядерні взаєлодї̈? Це взаємодії магнітних полів за польово теорією.

АНТИТЕЗА: "Польова теорія заперечує існування бозона Хіггса"

Нехай дійсно було відкрито бозон Хіггса. Як його ортимали на прискорювачах ВАК і Теватрон, ми знаємо, але як він може створюватися в Природі? Максимальна енергія, що виділяеться зірками під час термоядерного синтезу 18.77 MeВ, а потрібно 126 ГеВ. За час існування Всесвіту всі раніше ствоені бозони Хіггса розпались, а в природу їх вводять розумні істоти на прискорювачах в мікроскопічній кількості. Чому тоді не зникла маса у Всесвіті [16]? Стандартній моделі і Квантовій теорії потрібно було пояснити, звідки взялася маса у елементарних частинок і було вигадано власний механізм наділення ïх масою. Розглянемо знову це питання. У кожної елементарної частинки, крім фотона, є постійне электричне і магнітне поле, а також змінне електромагніте поле. Далі додаємо енергію всіх полів і ділимо на квадрат швидкості світла (згідно 3 формулою Ейнштейна):

$$
m_{0}=\frac{1}{8 \pi c^{2}}\left(\int\left(E^{2}+H^{2}\right) d v\right)
$$

де $m_{0}$ - маса спокою елементарної частинки.

Прихильники польової теорії вважають, що замість бозона Хіггса була відкрита звичайна елементарна частинка - бозон (або векторний мезон, згідно польовій теорії). Фотон - єдина елементарна частинка 3 нульовою масою, змінне електромагнітне поле фротона лінійне, воно неперервно рухатеться зі швидкістю світла. Гравітаційне поле $є$ проявом електромагнітного поля. Квантова теорія і Стандартна модель створили кварки i квантову електродинаміку, яка ігноруе закон збереження енергії. Наявність в природі, крім гравітаційного поля, інших полів, в тому числі всередині елементарних частинок, не встановлено. Польова теорія встановила, що кінетична енергія електромагнітного поля елементарноі частинки дорівнюе кінетичній энергії її інертної маси. Частина елементарних частинок має заряд, тобто, у елементарних частинок $є$ постійне електричне поле. Це може бути як поле елементарного заряду, так і дипольне поле, в якому заряд є асиметричною різницею дипольних зарядів. Наявність дипольного поля узгоджується 3 нейтральними частинками, які також можуть мати таке поле, але завдяки симетрї зарядів на великих відстанях воно не помітне. Аналогічно електричному полю, для елементарних частинок вводяться дипольні магнітні поля і всі вони об'єднуються в постійну компоненту електромагнітного поля. Всередині елементарних частинок є змінне електромагнітне поле з постійною складовою. Причому, змінне електромагнітне поле обертається по визначеному радісу - радіусу елементарної частинки. Для отримання частинок і античастинок треба ввести квантування поляризації обертання електромагнітного поля. А саме: При обертанні електромагнітного поля в площині електричної складової, маємо заряджену частинку і античастинку (заряд утворюеться внаслідок асиметрії між потоками зовнішнього і внутрішнього заряду). При обертанні в площині магнітної складової (перпендикулярній електричній) маємо нейтральну частинку і античастинку. В цій ситуації електричні заряди диполів рівні, а різниця між частинками виникає в поляризації по відношенню до напрямку спіну. Частинка відрізняеться від своєї античастинки поляризацією електромагнітного поля. При зміні кута поляризації на $\pi$, ми отримаємо античастинку, а при зміні кута поляризації на $\pi / 2$ перейдемо від зарядженої частинки (античастинки) до нейтральної. Елемент невизначеності в поведінці частинок зв'язаний зі змінним електромагнітним полем. Результат взаємодії залежить від того, якою ділянкою поля вони зіткнулись. Крім того, електромагнітне поле самочинно переходить на більш низькі енергетичні рівні (з утворенням інших елементарних частинок).

Ідея про існування кварків виникла в зв'язку 3 ростом числа відкритих елементарних частинок під час спроби їх систематизувати. Вважається, що кварки відповідають унітарній симетрії Унітарна симетрія - це математична вигадка, засіб для систематизації. Польова теорія вирішила це завдання без використання кварів.

В Стандартній моделі вважається, що в віртуальному стані елементарні частинки $є$ переносчиками взаємодій між частинками і переміщуються зі швидкістю світла, і що закон збереження енергії може не виконуватись в проміжок часу $\Delta t$ на величину $\Delta E=\frac{h}{\Delta t}$. Але це твердження про дискретний характер взаємодій суперечить законам природи і експериментальним даним. А чому не допустити наявність взаємодії електричних полів? Так, енергія $U$, електричного поля напруженістю $E$ буде: $U=\frac{1}{8 \pi} \int E^{2} d v$ (інтеграл береться по всоьму полю), і невизначеність зникає.

Що таке ядерні взаєлодї̈? Ядерні взаємодії спочатку є силами притягання, а на меншій відстані перетворюються в більш потужні сили відштовхування. Польова теорія [16] встановила природу цих сил - а саме: ядерні взаємодії $є$ взаємодіями постійних магнітних полів нуклонів в ближній зоні. Ядерні сили мають магнітну природу і виникають внаслідок постійного струму, що породжуе рухома заряджена частинка.

А якщо припусити, що ядро є кристалом з протонів і нейтронів, що зв'язані між собою іонними кристалічнми зв'язкам, які і є ядерними силами. Так, ядро гелію - це кристалічнй чотиригранник (рис. 2), а ядро літію - шестигранник, а більш масивні ядра складаються 3 шестиграннків, як бжолині соти.

3 формули Ейнштейна $\left(E=m_{0} c^{2}\right)$ можна зробити висновок: в елементарній частинці є деяка розподілена маса $\left(m_{0} \sim m_{0}\right)$, що обертається зі швидкістю кванта електромагнітного поля (c). Тобто, всередині елементарних частинок обертається змінне електромагнітне поле (масою $m_{0} \sim$ ), в якому зосереджено 90\% всієї внутрішньої енергії [16]. Декілька процентів енергії частинок зосереджено в постійному електричному і магнітному полі. У маси $m_{0} \sim$ повинен бути і обертовий момент $m_{0} \sim c r$ (де $r$ - середній радіус обертання). Проквантуемо його кратно $\hbar / 2$ (де $\hbar-$ постійна Планка) Тоді радіус елементарної частинки $\left(r_{0} \sim\right)$, як середньої відстані від центру елементар- 


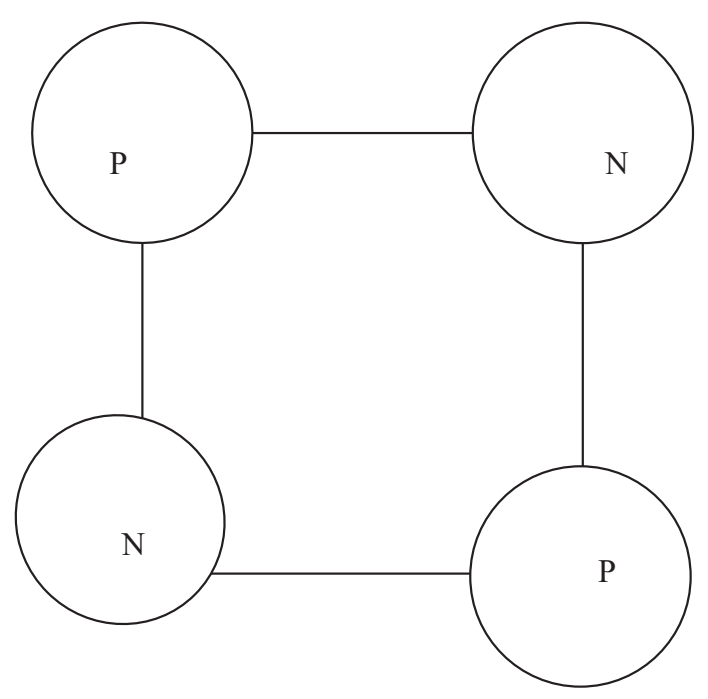

Рис. 2. Атом гелію

ної частинки (з квантовим числом $L>0$ ), на якій обертається змінне електромагнітне поле буде: $r_{0 \approx}=\frac{L \hbar}{m_{0 \approx} c}$, а радіус області, що займає елемен-

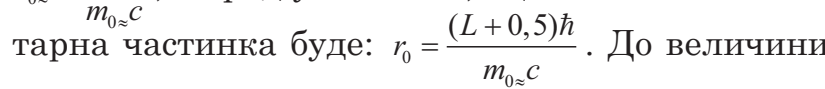
$r_{0} \sim$ додався ще радіус кільцевої зони, що займає змінне електромагнітне поле.

У заряженої частинки виділяють два електричні заряди і два електричні радіуси:

Для від'ємно заряженої частинки (рис. 4). електричний радіус зовнішнього постійного електричного поля (заряду -1.25e) $-r_{q-}$. Електричний

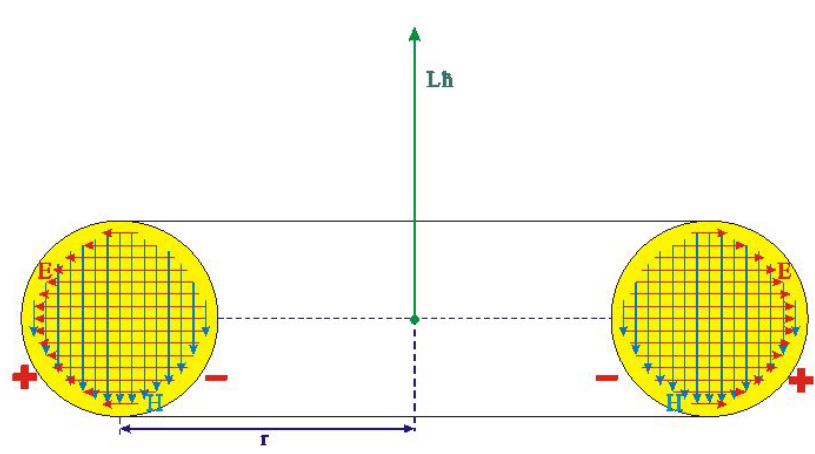

Рис. 3. Будова протона в польовій теорії (поперечний розріз) ( $E$ - постійне електричне поле, $H$ - постійне магнітне поле, жовтим кольором відмічене змінне електромагнітне поле) Джерело: [16]

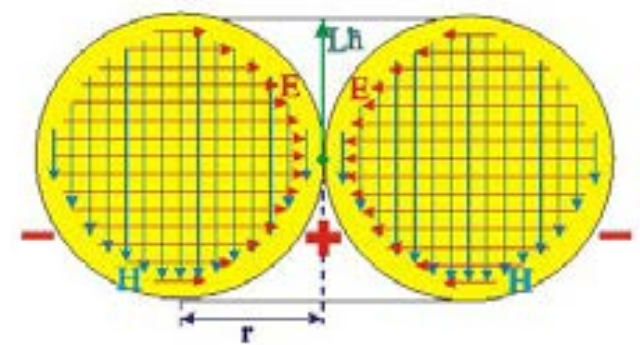

Рис. 4. Будова електрона в польовій теорії (поперечний розріз) радіус внутрішнього постійного електричного поля (заряду $+0.25 e)-r_{q+}$.

Для додатньо заряженої частинки (рис. 3) електричний радіус зовнішнього постійного електричного поля (заряду $+1.25 e)-r_{q+}$. Електричний радіус внутрішнього постійного електричного поля (заряду $-0.25 e)-r_{q-}$.

Електричний радіус вказуе середне місцезнаходження рівномірно розподіленого по колу електричного заряду. Обидва електричні заряди лежать в площині обертання змінного електромагнітного поля і мають один з ним центр обертання .

Будь-яка елементарна частинка $3 L>0$ володіє дипольним електричним полем. У випадку нейтрино $(L=1 / 2)$, це буде електричне поле двох паралельних симетричних кільцевих зарядів $(+0.75 e$ i -0.75e) (рис.4). Електричні заряди близькі до заряду гіпотетичних кварків $(+2 / 3 e=+0.666 e$ $i-2 / 3 e=-0.666 e)$ в нейтроні.

Електричне поле нейтральних частинок буде взаємодіяти з зарядженими частинками.

На схемі електрон менше протона, а насправді його польовий радіус в 600 разів більше протонного, отже впасти на ядро електрон не може - лінійні розміри електрона більші за розміри будь-якого атомного ядра. В $m_{0} \sim$ зосереджена лише частина маси спокою елементарної частинки: $m_{0} \sim=m_{0}-m_{0}=$

Таким чином, польова теорія елементарних частинок знайшла відповідь на наступні запитання: чому елементарні частинки мають корпускулярні і хвильові властивості; з чого складаються елементарні частинки; звідки береться маса частинки і т.д. 3 допомогою польовоі теорії були здійснені відкриття в області фрізики нейтрино, мікрохвильового фронового космічного випромінювання, червоного зміщення, знайдено природний імітатор “Темної матерії”. Пролітання фотона через електронне нейтрино (що в великій кількості викидається зірками) зменшувє енергію фотона. I чим більше фротон зустріне електронних нейтрино, тим більшим буде червоне зміщення. Отже, немає прямих доказів того, що галактики розбігаются. Тобто, “теорія Великого вибуху” не є доказаною. Під час зіткнення електронних нейтрино, вони перейдуть у збуджений стан, тоді здійсниться їх перехід в стан з меншою енергією з випромінюванням фотонів, і виникає ілюзія утворення пари частинка-античастинка, а також виникнення електромагнітного випромінювання, що приписується “реліктовому”. Елек-

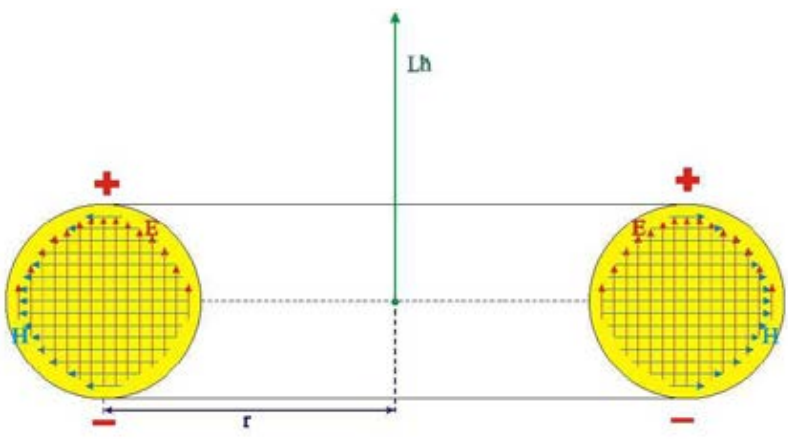

Рис. 5. Будова нейтрона в польовій теорії (поперечний розріз) 
тронні нейтрино, після злиття в молекулярне $\left(v_{e 2}\right)$, будуть поповнювати невидиму масу - темну матерію. При цьому виділяеться енергія у вигляді кванта випромінювання. Величині енергії такого фотона $0,72 \cdot 10-3 е B$ відовідає довжина хвилі 1,64 мли, що узгоджуеться 3 довжиною хвилі максимума фонового космічного випромінювання $(1,9$ мл). Якщо Всесвіт розшиюеться, то збільшуються і лінійні розміри, тобто, збільшуеться довжина еталона - метра. Отже, неможливо визначити розширення Всесвіту - число метрів віддаленої галактики буде залишатися незмінним.. Згідно з польовою теорією чорна діра в природі існувати не може. Спрощуванням в Стандатній моделі картини мікросвіту, шляхом ігнорування структури елементарних частинок - дійсна картина замінюеться міражем [16].

Запитання: Що змушуе змінне електромагнітне поле рухатись по колу всередині частинки? Де це поле було реально зафріксоване? Яка довжина хвилі цього поля? Чому маса протона більша маси електрона? (протон має сильніше змінне ЕМ поле?)

Висновки і пропозиції. Теорію гравітації під час дискусії було розглянуто з різних точок зору. Було висловлено зовсім протилежні думки та погляди. Отже, для розв'язку цьго питання, треба шукати компроміс. Можливо, саме сучасним школярам і належить вирішити цю проблему. Перед тим як почати дослідження, необхідно визначити концепцію дослідження. В статті, на прикладі дискусії про природу гравітаційного поля, показано розвиток сучасної наукової думки. Історія фізики вчить нас, що провідними критеріями істинності теорії виступають її формально-логічна бездоганність і підтвердження експериментом. До розгляду повинні бути прийняті, як істинні, самі божевільні ідеї, якщо вони внутрішньо бездоганні і хоча б побічно експериментально підтверджені. Гравітацію необхідно досліджувати на основі головних ідей нової фрізики. Реалізація проблемного навчання на основі дискусії, використання методів пошукового характеру є едективним засобом активізації навчально-пізнавальної діяльності. Для успіху в наукових дослідженнях потрібна копітка дослідницька робота та використання сучасних методів пізнання, які необхідно засвоїти ще під час шкільного навчання. Нарощування змісту і новизни матеріалу; надання учням свободи для виявлення творчих можливостей; творче ставлення викладачів до викладання предмету дає вагомі результати у пошуках істини. Найважливіша роль у цьому процесі належить школі, навчання в якій має бути підпорядковане ідеї розвитку творчих здібностей учнів. Однією з основних умов розвитку мислення є створення атмосфери, яка сприяе появі нових ідей і думок.

\section{Список літератури:}

1. Атаманчук П.С. Управління процесом навчально-пізнавальної діяльності. Кам'янець-Подільський : Кам'янець-Подільський державний педагогічний інститут, 1997. 136 с.

2. Богоявленская Д.Б., Петухова И.А. Умственные способности как компонент интеллектуальной активности. Психологические исследования интеллектуальной деятельности; под ред. О.К. Тихомирова. Москва : Наука, 1979. C. $17-28$.

3. Буева Л.П. Человек, деятельность, общение. Москва : Мысль, 1978. 216 с.

4. Бурлачук Л.Ф., Келесі М. Про критерії розвитку особистості. Вісник Київського університету. Серія : Cоціологія. Психологія. Педагогіка. Вип. 2. Київ, 1996. С. 90-93.

5. Візгін В.П. Єдині теорії в 1-ій третині ХХ ст. Москва : Наука, 1985. 304 с.

6. Возняк Л.С. Психологічні особливості профресійної підготовки майбутніх спеціалістів до управлінської діяльності: Автореферат. Київ, 2000. 19 с.

7. Галатюк Ю.М., Рибалко А.В. Керування пізнавальною діяльністю учнів за допомогою навчально-діагностичних завдань. Теорія $і$ методика навчання математики $і$ gбізики. Збірник наукових праць. Кривий Ріг : T. 2. 2002. C. 61-68.

8. Гальперин П.Я. О формировании умственных действий и понятий. Культурно-историческая психология. 2010. № 3. С. 111-114.

9. Іваненко Д.Д., Сарданашвілі Г.А. Гравітація. Москва, 2008. 200 с.

10. Лернер И.Я. Проблемное обучение. Москва : Знание, 1974. 144 с.

11. Матюшкин А.М. Проблемные ситуации в мышлении и обучении. Москва : Педагогика, 1972. 208 с.

12. Талызина Н.Ф. Управление процессом усвоения знаний. Москва : МГУ, 1984. 344 с.

13. Шут M.І., Сергіенко В.П. Науково-дослідна робота з фізики у середніх та вищих навчальних закладах : Навчальний посібник. Київ : Шкільний світ, 2004. 128 с.

14. У пошуках хвиль, не знайдених Ейнштейном. Ребекка Морель Науковий кореспондент, BBC News 30 листопада 2015. URL: http://daleki-zori.com.ua/category/novini/doslidzhenya-ta-vidkrittya

15. Бозон Хиггса - крайне важно и загадочно. URL: http://www.gazeta.ru/science/2012/07/03_a_4661569.shtml

16. Физика 21 века Теория гравитации елементарных частиц Copyright БГУ физфак Горунович В.А. (C) 2017. URL: http://www.ucoz.ru

\section{References:}

1. Atamanchuk P.S. (1997) Upravlinnya procesom navchalno-piznavalnoyi diyalnosti [Management of the process of cognitive activity]. Kamyanec-Podilskiy: Kamyanec-Podilskiy state pedagogical college. (in Ukrainian)

2. Bogoyavlenskaya D.B., Petukhova I.A. (1979) Umstvennyye sposobnosti kak komponent intellektual'noy aktivnosti [Intellect capabilities as component of intellectual activity]. Psychological researches of intellectual activity; under red. O.K. Tikhomirova. Moscow: Science. (in Russian)

3. Buyeva L.P. (1978) Chelovek, deyatel'nost', obshcheniye [Man, activity, communication]. Moscow: Mysl, 216 p. (in Russian)

4. Burlachuk L.F., Kelesi M. (1996) Pro kryteriyi rozvytku osobystosti [On the criteria of personality development]. Bulletin of the University of Kiev. Series: Sociology. Psychology. Pedagogy, vol. 2, pp. 90-93. (in Ukrainian)

5. Vizhin V.P. (1985) Yedyni teoriyi v 1-iy tretyni XX st. [Unified theories in the 1st third of the twentieth century]. Moscow: Nauka, p. 304. (in Ukrainian)

6. Voznyak L.S. (2000) Psykholohichni osoblyvosti profesiynoyi pidhotovky maybutnikh spetsialistiv do upravlins'koyi diyal'nosti [Psychological features of professional training of future specialists in management]. Psychological 
features of professional training of future specialists in management: abstract dis. Cand. psi-hall. Science. Kyiv, p. 19. (in Ukrainian)

7. Halatyuk Yu.M., Rybalko A.V. (2002) Keruvannya piznaval'noyu diyal'nistyu uchniv za dopomohoyu navchal'nodiahnostychnykh zavdan' [Management of students' cognitive activity with the help of educational and diagnostic tasks]. Theory and methods of teaching mathematics and physics. Collection of scientific works / Ed. department. Nau. MetAU. Kryvyi Rih: t. 2, pp. 61-68. (in Ukrainian)

8. Gal'perin P.Ya. (2010) O formirovanii umstvennykh deystviy i ponyatiy [On the formation of mental actions and concepts]. Cultural and historical psychology, no. 3, pp. 111-114. (in Ukrainian)

9. Ivanenko D.D., Sardanashvili G.A. (2008) Hravitatsiya [Gravity]. Moscow, p. 200. (in Ukrainian)

10. Lerner I.Ya. (1974) Problemnoye obucheniye [Problem-based learning] Moscow: Knowledge, p. 144. (in Russian)

11. Matyushkin A.M. (1972) Problemnyye situatsii v myshlenii i obuchenii [Problem situations in thinking and learning]. Moscow: Pedagogy, p. 208. (in Russian)

12. Talyzina N.F. (1984) Upravlenie processom usvoeniya znaniy [Management by the process of mastering of knowledges]. Moscow: MGU. (in Russian)

13. Shut M.I., Sergienko V.P. (2004) Naukovo-doslidna robota z fizyky u serednih ta vyshhyh navchalnyh zakladah [Research work is from physics in middle and higher educational establishments]. Kyiv: School world. (in Ukrainian)

14. In search of waves, not found Einstein. Rebekka Morel the Scientific correspondent, BBC News on November, 30 2015. URL: http://dalki-zori.com.ua/category/novini/doslidzhenya-ta-vidkrittya

15. Bozon Khiggsa - krayne vazhno i zagadochno (2012) [Bozon Khyhhsa - krayne vazhno y zahadochno]. URL: http://www.gazeta.ru/science/2012/07/03_a_4661569.shtml

16. Gorunovich V.A. (2017) Fizika 21 veka Teoriya gravitatsii yelementarnykh chastits [Physics of the 21st century Theory of gravitation of elementary particles]. Copyright BSU Fizfak Gorunovich V.A. (C URL: http://www.ucoz.ru 